\title{
Study of investors' reaction to circulation capital/money (Study of the Tehran Stock Exchange)
}

\author{
Jalileh Amini \\ Department of Accounting, Kurdistan Science and Research Branch, Islamic Azad University, \\ Sanandaj, Iran
}

\section{Dr. Ataollah Mohammadi}

Department of Accounting, Sanandaj Branch, Islamic Azad University, Sanandaj, Iran

DOI: $\quad 10.6007 /$ IJARBSS/v4-i2/648 URL: http://dx.doi.org/10.6007/IJARBSS/v4-i2/648

\begin{abstract}
The main objective of this research is to study the effect of investors' reaction to circulation capital in Tehran Stock Exchange. In this research, the circulation capital as independent variables and the reaction of investors (unusual return) have been considered as dependent variable and multi variable regression as well as the ' $t$ ' student statistical test have been used to test hypothesis/supposition. The statistical society of research was the whole accepted companies in Tehran stock exchange during 2006 until 2011and the statistical sample volume is also equal to 120 companies considering the sieving method and after eliminating the outlier observation. The results obtained by the analysis of 120 companies during 2006 until 2011 at satisfactory level of $95 \%$ indicate that the reaction of the investors to circulation capital in the companies with higher financial leverage is lower than all other companies.
\end{abstract}

Keywords: Circulation Capital, Reaction Of Investors, Financial Lever

\section{Introduction}

Nowadays, application of the financial management issues has dedicated a special place in efficiency promotion of institution. Therefore, financing and investment decisions have a special importance as the two main functions of financial management. In this regard, management of Circulation capital which is very the current expenditures and sourses, to maximize shareholder wealth as a part of the scope of financial management issues are particularly important. Institutions managers should choice the appropriate strategy to managing the Circulation capital of their units, according to external and internal factors and risk and efficiency of the institution. If the kind of the strategy of current assets and current liabilities management being selected opportunity in a specific position, achiving the best strategy of Circulation capital management would be provided. Creation the balance in current assets and current liabilities is particular important; As decision about one of them has an enormous impact on other (Maleki Nia et al,2011). 
On the other hand the method to manage the circulation capital has significant effect on the flow of cash and performance/functioning of company. The shortening of cash conversion cycle causes the improvement of company's profiting since the lengthening the cycle of cash conversion requires expensing the costs for outward supply. Therefore, by decreasing the time duration for cash amount conversion, the company could have better performance (Moss and Stine, 1993). In Efficient market of capital the information's entry inflow with high mass has continued regularly, and Investors react to the new information. The rationally Reaction of investors cause to adjustment of securities price, for achieving the true (intrinsic) values. Due to the competitive conditions, Market makers to gain more returns than market, can not rely on past information or their personal skill. On the other hand, because of entering information randomly to the market, Predict the trend of stock prices is not possible even in the near future. Thus, investors can not increase their investment returns by using the specific investment strategies, such as comparative power and reverse investment strategies. In such markets, the implementation of specific investment strategies for identifying profitable investments, face to fail (Hagyn,1997).

\section{Significance and the need of research}

The subject of circulation capital management during 1995 to 2012 was studied abundantly in all countries. The general results of these researches in different stock exchanges of America, Belgium, India, Pakistan and turkey was almost the same and indicate that there is a significant and considerable relation between different components of circulation capital with profiting. Considering that: 1 - at present the cash status of the ..........Company is in appropriate conditions and the majority of Iranian Companies prefer to convert the cash amount to other assets due to the inflation present in the country and this theme causes that the companies desperate in paying their debit at due time and put the credibility of the organization under question.

2-the experience has indicated that most of the companies that encounter the financial insolvency al of a sudden, finally the fate of some of them ends in bankruptcy. One of the major causes of it is the mal management of circulation capital as well as the management of cash amount. Considering the above mentioned themes and in view that in Iran no research has dealt with the study and the comparison of investors' reaction to circulation capital in Tehran Stock Exchange, hence the need and significance of carrying out such research is felt double in this regard.

\section{Research record}

Grablasky (1976) indicated that there is a significant relation between different appraisals of success and the use of policies related to circulation capital. The management of circulatory cash and the conversion cycle of cash money is an important component of financial management of the companies, especially of the companies that have the capital limitation and more rely on short term financial resources. (Fama \& French 1981), researched on the efficiency of circulation capital and its' relation with interest using the cycle of net profit, the obtained result was that the management of circulation capital is only a part for several companies and a robust relation exists between net profit cycle and profiting rate of a company hence, the actual profit obtained from shortening of cycle period of net profit by reducing the assets rather increasing the imbursement. Anando and Prakash Gopta (2002) in his research 
studied the management performance of circulation capital of the companies between 1991 and 2001.

In this research 427 of the companies were selected as model companies. In this research, the efficiency standards of conversion cycle of cash amount, operational circulation cycle and capital circulation flow were used to assess the management of circulation capital of the companies. The research results indicated that the standards selected for assessing the management performance of circulation capital are useful in addition to assess the circulation capital management, also help for analyzing the risk and the productivity/efficiency of the companies.

Setayesh and Mansoori (2010) engaged in the study of relation between circulation capital and different components of accounting profit (including gross interest, operational interest, and interest before deducing the profit as well as taxes and net profit). The research results indicate that there is no significant relation between gross circulation capitals with none of the accounting profit components, while net circulation capital, operational profit and interest before deducing the profit as well as taxes and net profit have positive and significant relations. Mahmudi et al. (2011) investigated the study of investigators' reaction in relation to the changes of interest related to the stocks of the companies accepted in the stock exchange of Tehran. In this research, the mean of unusual agglomerative return has been used for measuring the reaction of investors. The obtained results are indicative of investors' reaction to the receiving/incoming information on the interest changes for the companies that announced positive change in their profit and the reaction was less than the positive limit while for the companies that had announced negative change in their profit, the reaction observed was less than the negative limit.

Rahnamye Rudposhti and kieaii(2008) investigated and explained the Circulation capital management strategies of companies listed inTehran Stock Exchange. The results showed that there was a poor correlation between productivity and Circulation capital management strategy, which was not statistically significant. But there was a significant relationship between liquidity and Circulation capital management strategy. Also, there was a significant relationship between the ability of debt payment and Circulation capital management strategy.

Asramy(2001) showed that there is a direct and significant relationship between Circulation capital and profitability. Also, he believed that a company which is not profitable is sick; So, according to this issue, role of managing the Circulation capital is more emanating.

Abzari et al(2003) in their reviews, at first indicated the importance of Circulation capital's management and its important role on the financial management's campass. Then, they surveid the exist strategies for achieving the strong management in Circulation capital ground, and explained their features and application circumstances of each of them.

\section{Research hypothesis/supposition}

supposition: the reaction of investors to the changes of circulation capital in the companies with higher financial leverage is less as compared with all other companies.

\section{Research Method}

Present research is of applied research type in terms of classification based on objective. The goal of applied research is the expansion of applied knowledge in a particular field. In addition 
the present research is of correlation research type in view of method and the nature. In this research, the objective is to determine the degree/rate of variables' relation. For this purpose, the appropriate indicators are adopted on the basis of the measuring scales of variables. The scale of data measuring is a relative scale. Relative scale presents the highest and most accurate level of measurement. This scale in addition to having the entire properties of other scales also enjoys the absolute zero. Research method is in deductive form in which the theoretical fundamentals and the research record has been aggregated through library, article and internet and deductive reasoning is used in generalizing the results by using the appropriate statistical methods in rejecting or proving the research hypothesis. Hence, the research conduction has been taken place in deductive reasoning framework. In a sense that in theoretical fundamentals and research records the articles are accomplished in the deductive framework and information collection to emphasize or rejecting the suppositions in deductive form through library based study of all sites.

\section{Research hypothesis test}

Supposition: the reaction of investors to the changes of circulation capital in the companies with higher financial leverage is less as compared with all other companies.

In this research the following regression model has been used for the research supposition test:

$$
\begin{aligned}
\mathrm{r}_{\mathrm{it}}-\mathrm{R}_{\mathrm{it}}^{\mathrm{B}}=\beta_{0} & +\beta_{1} \Delta \mathrm{C}_{\mathrm{it}}+\beta_{2} \mathrm{C}_{\mathrm{i}, \mathrm{t}-1}+\beta_{3} \Delta \mathrm{E}_{\mathrm{it}}+\beta_{4} \Delta \mathrm{NNA}_{\mathrm{it}}+\beta_{5} \Delta \mathrm{I}_{\mathrm{it}}+\beta_{6} \Delta \mathrm{D}_{\mathrm{it}}+\beta_{7} \mathrm{~L}_{\mathrm{it}} \\
& +\beta_{8} \mathrm{NF}_{\mathrm{it}}+\beta_{9} \Delta \mathrm{C}_{\mathrm{it}} * \mathrm{~L}_{\mathrm{i}, \mathrm{t}}+\varepsilon_{\mathrm{it}}
\end{aligned}
$$

After regression hypothesis test and satisfaction from their implementation, the results obtained from above regression equation fitting has been presented in table 1 . The $\mathrm{F}$ static $(21 / 651)$ is the significance indicative of whole regression model.

As it is specified in the lower part of table 1, the determination coefficient and the balanced determination coefficient of the above model is to be $54 / 1 \%$ and $50 / 8 \%$ respectively. Therefore this can be concluded in the mentioned regression equation, only about $50 / 8 \%$ of unusual return changes for under study companies are expressed by independent variables and the mentioned control. In this table the positive (negative) digits in the coefficient quantity column indicate the direct (inverse) effect rate of each of the variables on the unusual return of under study companies.

Test result: according to table 1 , the significance level of changes variable for circulation capital $(\triangle \mathrm{NWC})$ and the variable of interacting effect related to circulation capital changes as well as financial leverage $\left(\triangle N W C^{*} \mathrm{~L}\right)$ are $0 / 014$ and $0 / 000$ respectively. These values are less than the significance level considered in the present research (5\%); as well as the absolute value of $\mathbf{t}$ static related to these variables is greater than the $\mathbf{t}$ static obtained from table with the same freedom degree. Therefore, at $95 \%$ satisfaction level, the coefficients obtained for the above variables are significant in regression model. Hence, as the value of variable coefficient for the interacting effect of circulation capital changes and financial leverage (2/021) is less as compared to the variable of circulation capital changes (3/761), this can be claimed at $95 \%$ satisfaction level that the reaction of investors to circulation changes in the companies with 
high financial leverage is less as compared with all other companies, therefore the supposition is verified and confirmed.

\section{Results}

The final steps of research are among its most important and most fundamental steps. Accurate and careful analysis and making accurate and proper conclusions from collected data are even more important because they would be used as the bases for future planning in organizations, academic centers or studied population. As you know, current capital management has an important effect on cash turnover, and performance of a company. Analysis showed that most companies' encounter with financial distress, and finally their ending up in bankruptcy, is caused by improper management of current capital. The results of the reaction of the investors to circulation capital in the companies with higher financial leverage is lower than all other companies.

Given the findings of this research, it is recommended for the capital market players, decision makers, financial analyzers and potential and actual investors of stock exchange to consider, when evaluating companies, current capital variations according to company's financial leverage. It is also suggested for them to pay special attention to relations of capital structure (financial leverage), and current capital with investors' reaction as noted in this research, because consideration of this factor results in choice of optimal investment basket with minimum risk and maximum return. Besides, it doubles transparency of decision-making environment and the outcomes. Major limitation of the present research, which are present in findings, is that we could not use regression on company level (time series regression) due to shortness of time series of each company.

\section{References}

1- Abzry,M ; Shahshahani,M ; Jami,H.(2003). Circulation capital Strategies The pharmaceutical companies, Journal of Administrative Sciences and Economic university asfahan.

2-Anand,M \& Prakash gupta.(2002). Working capital performance of corporate india: An Empirical for the year 2000-2001. Management and accounting research January.pp:46-81.

3- Amry Asrmy,M.(2001). Examine The information content of earnings Circulation capital and cash flow, Masters thesis Tehran university, School of Management,32.

4-Fama.A \& Ferench.S.(1981). Efficiency of working capital management. Financial management, no.37,p5.

5-Grablowsky, B. J.(1976). Mis management of Accounts Receivable by small Business. Journal of Small Business,vol.14,pp:23-28.

6- Mahmudi,V;Shyrkvnd,S;Salary,M.(2011). The reaction of investors to changes in dividends of Listed companies in Tehran stock Exchange. Vision Financial Management and Accounting, vol,1,pp:115-130.

7- Malikinia,N ; Asgari,H ; Qizilbash,A.(2011). The Relationship Between Circulation Capital Strategies Profitability Criteria automotive and mineral Tehran Stock Exchange.Journal of monetary Economics, Financial, vol.18 , NO.2 , PP:140-162.

8- Moss,J.D.andstine ,B.(1993). Cash conversion cycle and firm size: a study of retail firms, managerial finance, vol.19, NO.8, PP: 25-34. 
9- Rvdpshty,R ; Kiai,F ; Kiai,A.(2008). Review and explanation of Circulation capital in Listed companies in Tehran stock Exchange, Knowledge of Accounting Research.

10-Setayesh,M. H; Mansoori,O.(2010). The relationship between the various components of working capital and profit enhancing Accounting firms Listed in Tehran Stock exchange. Journal of Accounting Auditing Financial.pp:1-24.

11- Haugen,R.A.(1997). Modern investment Theory.prentic Hall .inc.USA,pp:650-652.

\section{Annex}

Tab.1-Results obtained from regression equation fitting

\begin{tabular}{|c|c|c|c|c|}
\hline $\begin{array}{c}\text { Significance } \\
\text { level }\end{array}$ & t Static & $\begin{array}{l}\text { Coefficient } \\
\text { value }\end{array}$ & $\begin{array}{c}\text { Variable } \\
\text { coefficient }\end{array}$ & Variable name \\
\hline $0 / 000$ & $7 / 832$ & $0 / 806$ & $\beta_{0}$ & Constant digit \\
\hline 0/019 & 2/819 & 2/903 & ${ }_{1} \beta$ & $\Delta \mathrm{C}$ \\
\hline 0/0035 & $3 / 576$ & 2/987 & ${ }_{2} \beta$ & C \\
\hline 0/003 & $2 / 034$ & 2/051 & ${ }_{3} \beta$ & $\Delta \mathrm{E}$ \\
\hline 0/021 & $2 / 761$ & 0/913 & ${ }_{4} \beta$ & $\triangle N N A$ \\
\hline 0/049 & $-2 / 037$ & $-2 / 719$ & $\beta_{5}$ & $\Delta \mathrm{I}$ \\
\hline 0/039 & 2/091 & 0/741 & $\beta_{6}$ & $\Delta \mathrm{D}$ \\
\hline 0/004 & $-2 / 873$ & $-4 / 981$ & $\beta_{7}$ & $\mathrm{~L}$ \\
\hline 0/0037 & 2/987 & $1 / 311$ & $\beta_{8}$ & NF \\
\hline 0/014 & $2 / 847$ & 3/761 & $\beta_{9}$ & $\triangle N W C$ \\
\hline 0/000 & $5 / 073$ & 1/039 & $\beta_{10}$ & NWC \\
\hline $0 / 000$ & $6 / 158$ & $2 / 021$ & ${ }_{1} \beta_{1}$ & $\triangle \mathrm{NWC}^{*} \mathrm{~L}$ \\
\hline $21 / 651$ & \multicolumn{2}{|c|}{ F Static } & $0 / 541$ & $\begin{array}{c}\text { Coefficient } \\
\text { determination }\end{array}$ \\
\hline
\end{tabular}




\begin{tabular}{|c|l|l|l|}
\hline $0 / 000$ & (P-Value $)$ Significance & \multirow{2}{*}{$0 / 508$} & $\begin{array}{c}\text { Balanced } \\
\text { determination } \\
\text { coefficient }\end{array}$ \\
\cline { 1 - 2 } $1 / 571$ & Watson binocular static & & \\
\hline
\end{tabular}

Tab. 2- Descriptive statistics of variables

\begin{tabular}{|c|c|c|c|c|c|c|}
\hline Maximum & Minimum & Standard & Median & Average & \multicolumn{2}{|c|}{ Description of variables } \\
\hline$-0 / 233715$ & $-0 / 208075$ & $0 / 129165$ & $\begin{array}{c}\text { 010729 } \\
0\end{array}$ & $0 / 015348$ & $R_{i, t}-R_{m, t}$ & Return Unusual \\
\hline $0 / 275780$ & $0 / 035861$ & $0 / 066027$ & $\begin{array}{c}/ 151967 \\
0\end{array}$ & $0 / 154683$ & C & Cash balances \\
\hline $0 / 356062$ & $0 / 103562$ & 0/071712 & $\begin{array}{c}227990 \\
0\end{array}$ & $0 / 230250$ & $\mathrm{E}$ & Net Income Before Items \\
\hline $0 / 234854$ & $0 / 208755$ & $0 / 007818$ & $\begin{array}{c}/ 221527 \\
0\end{array}$ & $0 / 221618$ & NA & Net cash assets \\
\hline 0/162066 & 0/026849 & 0/038407 & $\begin{array}{c}091874 \\
0\end{array}$ & 0/093619 & I & Interest expense \\
\hline $0 / 458814$ & 0/000018 & $0 / 134794$ & $\begin{array}{c}/ 241789 \\
0\end{array}$ & $0 / 230348$ & D & Dividend \\
\hline $0 / 878297$ & $0 / 341153$ & $0 / 150132$ & $\begin{array}{c}592487 \\
0\end{array}$ & $0 / 597637$ & $\mathrm{~L}$ & Financial leverage \\
\hline $0 / 368881$ & 0/000911 & $0 / 107896$ & $\begin{array}{c}/ 190294 \\
0\end{array}$ & $0 / 187674$ & NF & $\begin{array}{l}\text { Net cash flow from } \\
\text { financing activities }\end{array}$ \\
\hline $0 / 832004$ & $0 / 305438$ & $0 / 157045$ & $\begin{array}{c}/ 557937 \\
0\end{array}$ & $0 / 561865$ & NNA & $\begin{array}{l}\text { Total assets minus cash } \\
\text { and investments }\end{array}$ \\
\hline $0 / 407615$ & $0 / 237884$ & $0 / 048817$ & $\begin{array}{c}/ 316754 \\
0\end{array}$ & $0 / 319450$ & NWC & Operating working capital \\
\hline
\end{tabular}

